\title{
End of Duopoly in Credit Card Payment Scheme Industry
}

\author{
Tapomoy Koley (B. Tech., Executive MBA - Finance)
}

\begin{abstract}
The market of Credit Card Payment Scheme Industry have long been dominated by two major players - Visa \& MasterCard. In the recent past the duopoly seems to be challenged by some emerging players of the industry. The paper tries to assess the existing market structure and discusses about the entry barriers of the market. It makes an attempt to find out direction of change and the reasons responsible for gradual change in market characteristics from duopoly to an oligopoly structure. The paper does detail analysis of strategies undertaken by some of the smaller players who have been successful to snatch significant market share from Visa \& MasterCard. It also tries to trace the future path.
\end{abstract}

\section{What is a Duopoly?}

Duopoly is a situation when there are only two firms in the market who produce and sell a particular goods or service for which there are no good substitutes and they produce a homogenous product. New firms are also prevented from entering in this type of market due to presence of steep entry barriers. However there can be more than two producers in a duopoly, but the top two should be having lion's share of the market. There can be several example of duopoly that can be found:

a) Soft drinks market, which is dominated by two major players Coca-Cola and Pepsi.

b) Large commercial passenger airplane market, which is dominated by Boeing and Airbus.

c) Australian grocery market, which is dominated by Woolworths and Coles.

There are several disadvantages of a market which has duopoly structure:

a) A duopoly market do have strong entry barriers which prevent smaller players to enter into the market. In absence of more market players innovative new products may not hit the market.

b) Absence of more number of producers in such market often forces the consumers to pay higher prices for the products / services. Consumers generally get advantage when they have a number of producers producing a homogenous product.

c) In a duopoly market there can be collusion between the two large players which may force consumers paying much more price than the actual product cost.

\section{What is a credit card payment scheme?}

Apart from card holder and merchant there are three other major and essential stake holders in credit card industry - Issuer, Acquirer and Credit Card Payment Scheme. Payment scheme acts as an intermediate player between acquirer and issuer.

a) Issuer: Issuer is a bank or a financial institution that has issued the credit card to the card holder. To the cardholder issuer acts as a single point of contact. Once a cardholder applies for a card after suitable background check regarding credit worthiness the card credit card is issued. For the issuer giving a credit card is almost analogous to giving an unsecured loan as the cardholder is expected to pay the issuer only after month end. Moreover the card holder is entitled for revolving credit facility whereby he can pay up only the minimum balance due and not the full due amount. Generally issuers do have different types credit card (with different benefits and features) to woo different set of customers. A logo of the issuer is displayed on top of the plastic card which helps to quickly identify the card issuer.

b) Acquirer: Acquirer is a bank or a financial institution that provides the infrastructure to merchant to accept \& process credit card transactions. To the merchant the acquirer acts as a single point of contact. The merchant may have accepted cards belonging to 50 different issuers (or even more) throughout the day but it will not reach out to each one of them for receiving the payment. Instead it will reach out to its acquirer with the transaction details and will receive payment from it. The acquirer will process those transactions and would receive money from the issuers. The merchants are provided with a POS device (Point Of Sale machine) by the acquirer, which is where the credit card is swiped. Generally the logo and name of the acquirer is displayed on the POS machine. The two copies of the sales draft which comes out of the POS machine (one is signed by the cardholder \& returned back to the merchant while the other one is retained by the cardholder) also has the logo and name of the acquirer. 
c) Credit card Payment Scheme: It is a financial organization who lays down the rules of processing a credit card and also facilitates the processing of transactions. All communication (transfer of data) and transfer of funds between Issuer and Acquirer generally flows via payment scheme. Both issuer and acquirer have to comply the rules and regulations laid down by the payment scheme and remain compliant on an ongoing basis. The logo of the payment scheme is displayed in the card. Some merchants also prefer to display logo of the payment schemes outside their shop to let their prospective customers know the card brands that they would honor.

\section{Existing structure of credit card payment scheme market}

Historically there have been two major players in credit card payment scheme market - Visa and MasterCard. Apart from them currently there are three other players Chinese UnionPay, American Express (popularly called Amex) and Japanese JCB who have more than $1 \%$ share in global credit card transaction volume. The below charts depict the worldwide credit card purchase transaction by count, purchase transaction by volume and number of credit cards in circulation in 2013 for those top 5 players. Other smaller players whose global share is less than $1 \%$ have been ignored in the below analysis.

Analysis of worldwide credit card purchase transaction count reveals that Visa \& MasterCard together still hold a commendable share of 61.68 Billion credit card purchase transaction which translate to a share of $81 \%$ when compared among the top 5. UnionPay with $9 \%$ market share (6.86 Billion transaction count) comes third, closely followed by Amex with $8 \%$ market share (6.33 Billion transaction count) and JCB occupies the $5^{\text {th }}$ place with $2 \%$ market share (1.89 Billion transaction count).

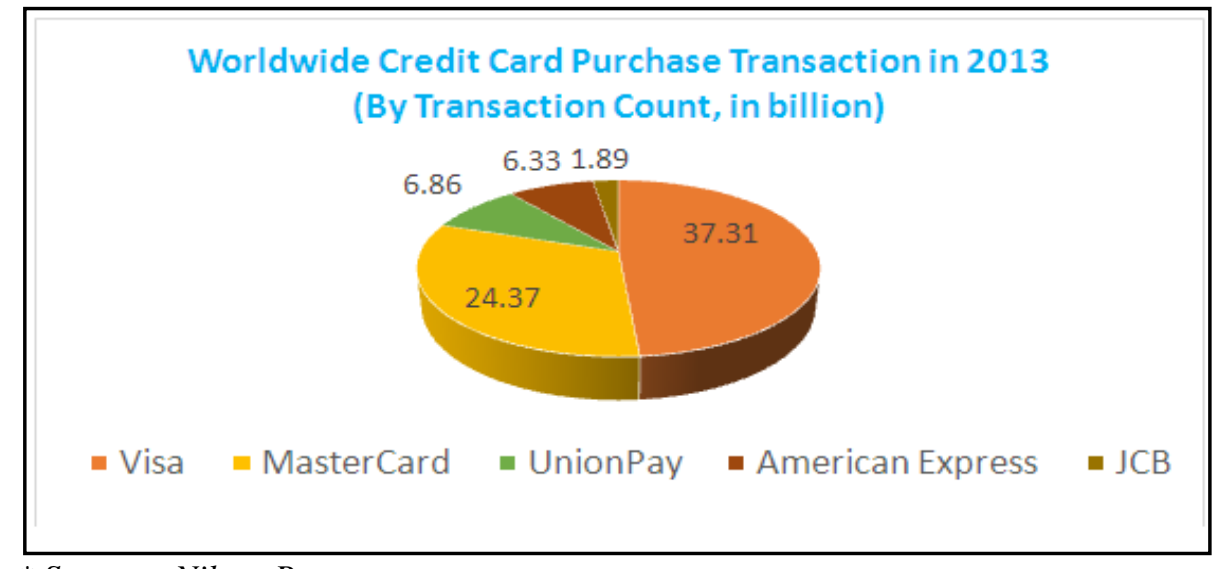

* Source-Nilson Report

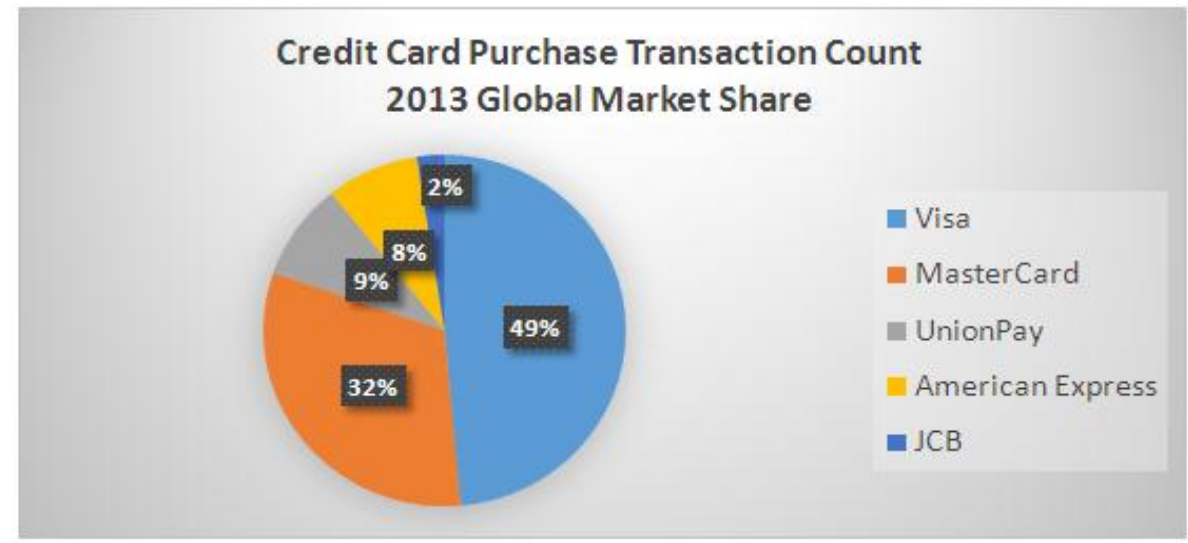

* Source-Nilson Report 
Among top 5 players if we compare in terms of cards in circulation Visa \& MasterCard's combined card base of 1644.5 million would translate to a share of $74 \%$. UnionPay has $17 \%$ share in this segment followed by Amex (5\%) and JCB (4\%). Except Visa and MasterCard the other three players are having 26\% global market share with them. Interestingly UnionPay alone has occupied more than $1 / 6^{\text {th }}$ of the total global card count which is in all ways amazing for a player who started its journey only in 2002.

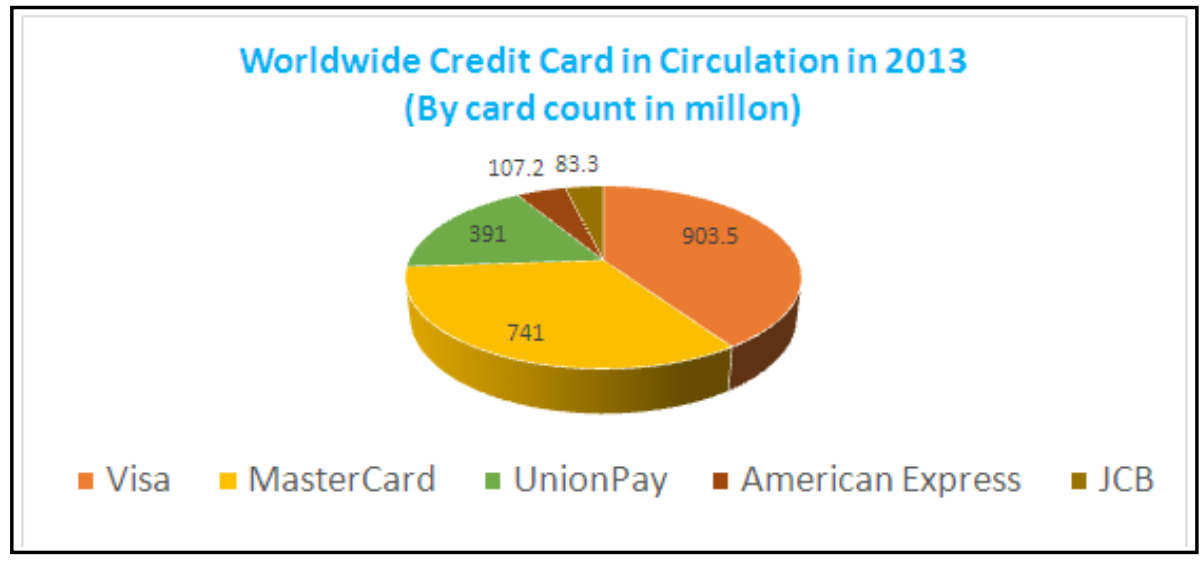

* Source-Nilson Report

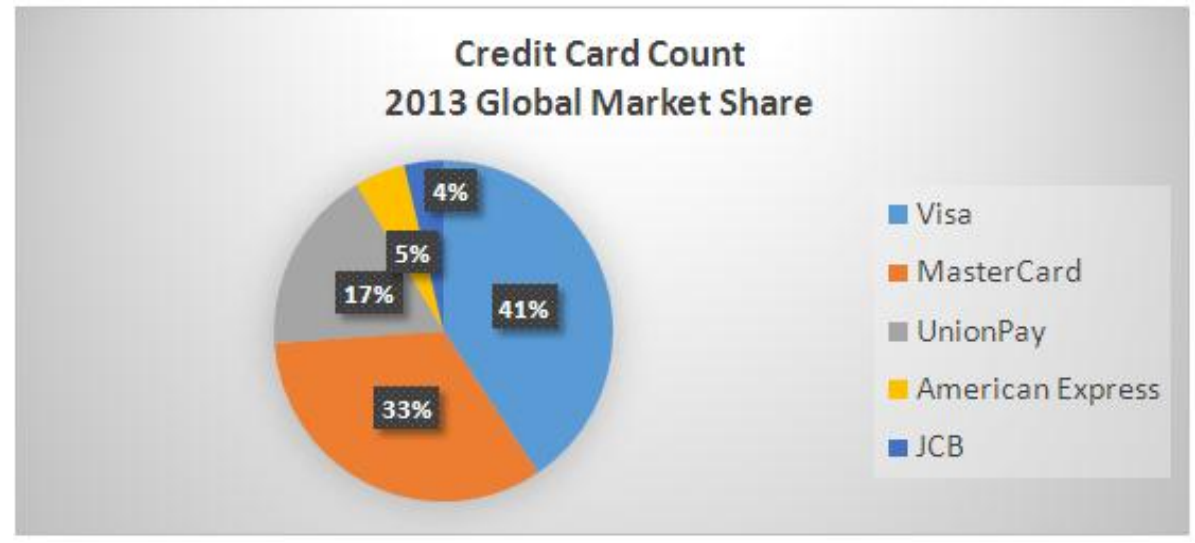

* Source-Nilson Report

The dominance of the big duo Visa \& MasterCard would appear to have further weakened by other three players if we analyse the credit card purchase transaction by volume data. The combined volume of $\$$ 5210.35 Billion credit card purchase transaction of the big duo translates to a share of $65 \%$. While the other three players are having a commendable 35\% global market share with them. In fact Union Pay's global market share of $21 \%$ is pretty close to MasterCard's share of $26 \%$. Amex with $12 \%$ share and JCB with $2 \%$ share occupies the last two positions.

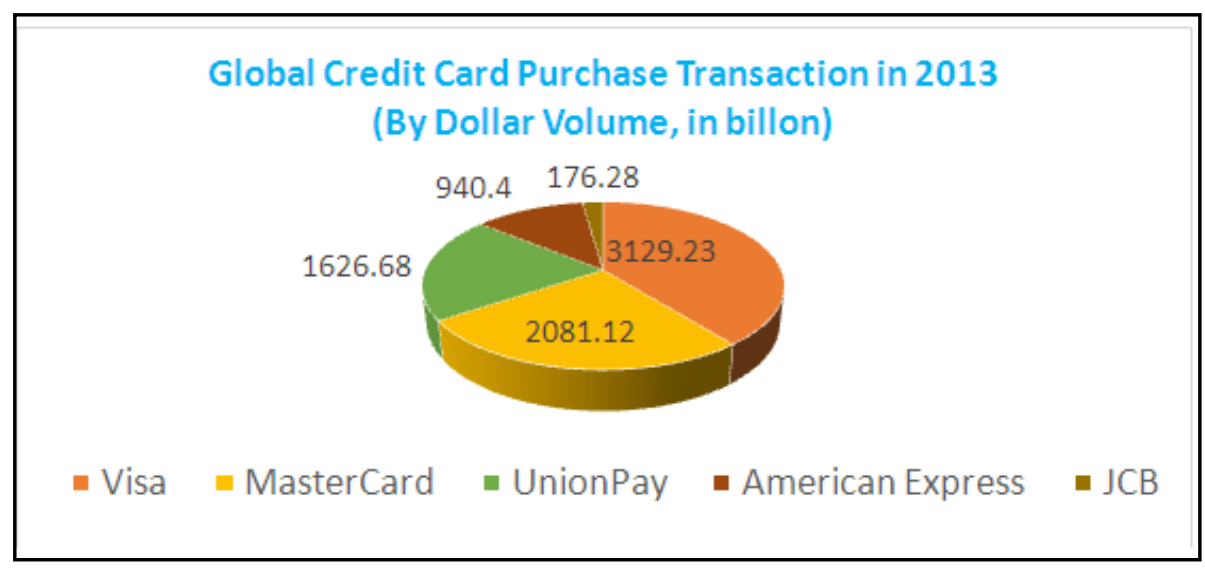

* Source-Nilson Report 


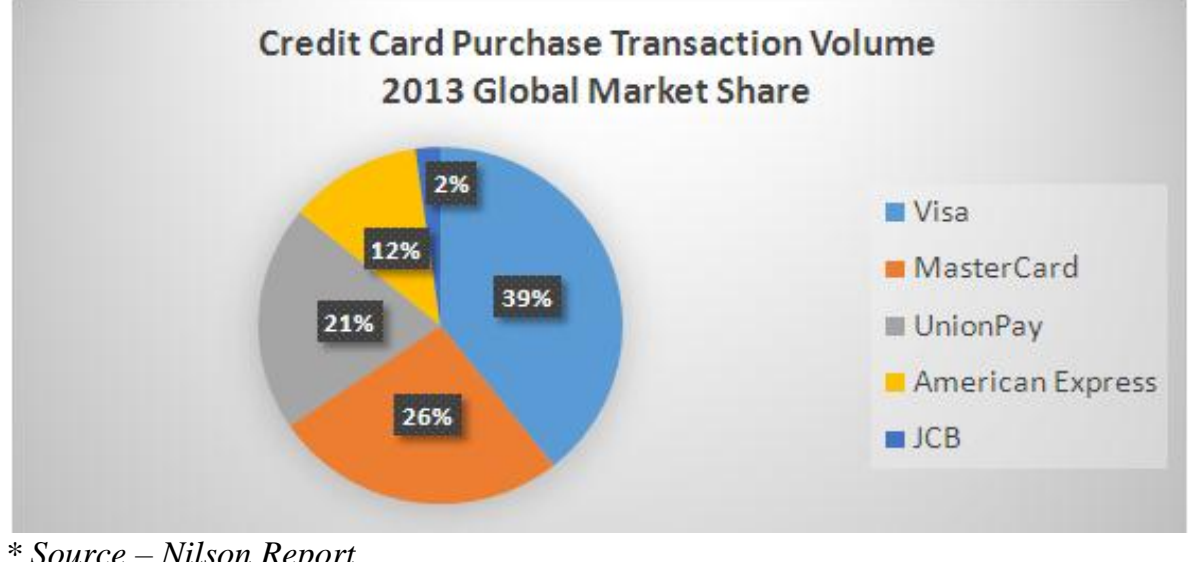

The 2013 global data analysis also reveals a very interesting fact. Most analysts taking a look at the global credit card purchase transaction count or the credit card purchase volume or the number of credit cards in circulation, would surely conclude that the market appears to be very attractive for any player to enter. Naturally they may expect a number of players in the market. However the existing market structure tells a different story as the market is having only 5 prominent players.

\section{Entry Barriers in the market:}

There are steep entry barriers in the credit card payment scheme market which make entry of any new player extremely difficult. In the past the three global challengers of Visa \& MasterCard - UnionPay, Amex and JCB had to overcome them to enter in the market, to survive in the hostile environment and also to snatch significant market share.

a) Low profit margin business model: In credit card industry apart from cardholder and merchant there are three other intermediate players - the Issuer, the Credit card payment scheme and the Acquirer. Each of these intermediate players would take some amount of money as their fees from the cardholder's total due amount to the merchant and delivers the rest to the merchant. The fee taken by Issuer is termed Interchange Fee, fee taken by Acquirer is termed as Acquirer Processing Fee and the fee taken by Payment Scheme is called Assessment Fee. The fees charged by the three players vary based on the risk borne by them and/ or the service they are providing. The Issuer pays the other parties before receiving the money from the cardholder and hence he is taking risk of the cardholder (by giving money on his behalf the issuer is almost giving the cardholder an unsecured loan). This risk is the maximum risk compared to other two players, hence the Interchange Fee is also the highest. Next comes the Acquirer processing fee charged by the acquirer, who has taken risk of the merchant and is required to pay for any fraudulent merchant activity. The Payment scheme does not take any risk, it only acts as a facilitator and governing body. Hence Assessment fee charged by the payment scheme is by far the lowest. Though the amount of the fees that is to be deducted varies depending on the risk associated with the transaction (e.g. Internet based ecommerce transactions are considered to be more risky than a transaction done at a brick \& mortar store) but in all cases the Assessment fee is always very low compared to Interchange fee or acquirer processing fee. A typical example of a $200 \$$ transaction and the corresponding fees is given below:
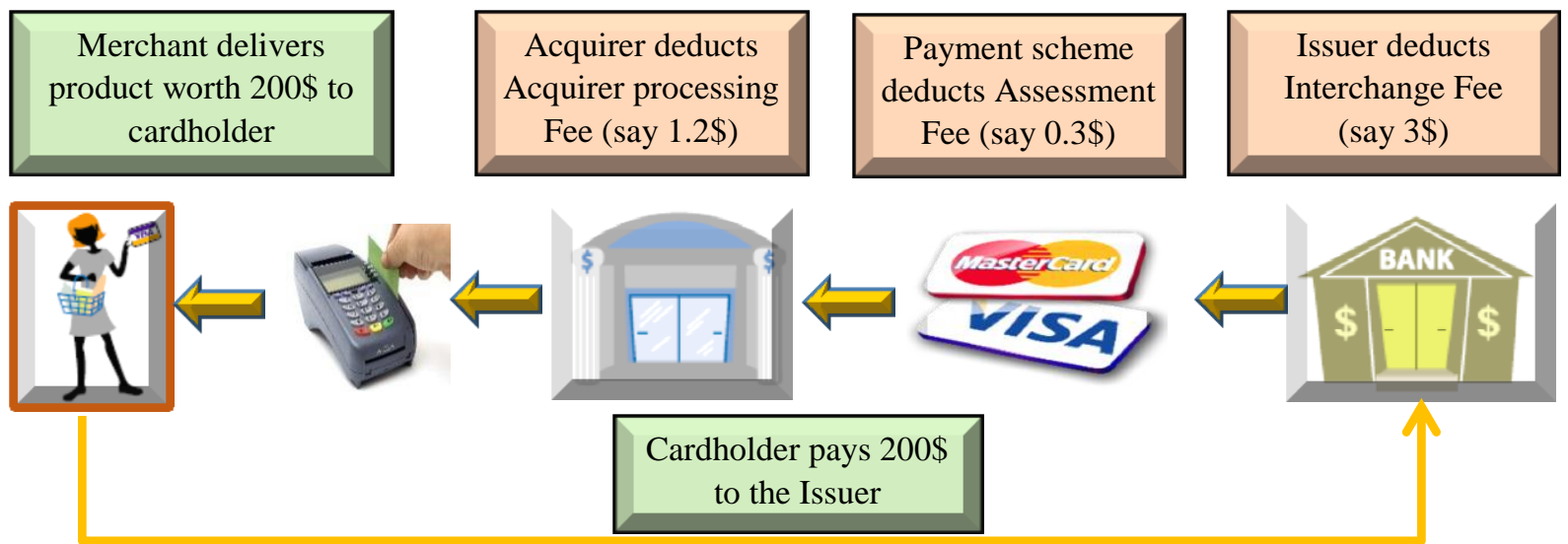
As the assessment fee is very low, essentially the business model is a low profit margin business model. In order to sustain as a payment scheme any player has to operate in high volume to recover its operating cost and make overall profit. This acts as a huge entry barrier for any new entrant.

b) Economies of scale: As huge volume of transactions are getting processed through the dominant players like Visa and MasterCard, they are comfortably leveraging on the economies of scale. However a new entrant for its low transaction volume often faces the problem in charging the same fees as that of the big players and still make profit.

c) Difficult to reach Break-even point: As the fee earned from each transaction is very low it becomes very difficult to reach Break-even point (a point where a firm is able to cover both its fixed cost and variable cost) and start making profit unless the new entrant start processing good volume of transactions.

d) Network Externality: There is a huge cardholder base of Visa and MasterCard and also most of the merchants do accept these two card brands. Thus it creates a positive network effect among the end users and for obvious reason they are reluctant to try any new card scheme.

e) Preference of Card Issuer Banks\& Acquirers: Card issuer banks and Acquirers would be encouraged to incur additional cost to process a card brand only when they are assured of its volume, which is mostly uncertain for new entrants. Naturally both the parties would be reluctant to accept new card scheme.

f) Brand Loyalty: A strong brand loyalty of common people towards Visa and MasterCard makes market penetration very difficult.

g) High Capital Investment: To work as a payment scheme an organization needs to do high capital investment for its software and hardware requirements. Due to sensitive nature of the data that is to be handled by the card schemes they need to invest highly on fraud protection measures to protect the interest of the cardholders and keep investing on a continuous basis devising new ways to stop fraudsters.

\section{Change in duopoly market structure:}

Analysis of existing market structure have already hinted at the erosion of market share of Visa and MasterCard who had complete dominance in the market in the past. We have also discussed the entry barriers of the market which are indeed difficult to overcome. However despite presence of steep entry barriers there are three extremely important milestones in the global credit card industry which have been responsible for gradual change in duopoly market structure:

a. Launch of Optima card by American Express in 1987 which is their first credit card product.

b. $\quad$ Aggressive overseas business expansion attempt by JCB since 1981 .

c. Launch of UnionPay in 2002.

Of all three, launch of Chinese UnionPay is by far the most significant one.

\section{Study of Year on Year Change in the Global Market:}

In order scrutinize further the direction and pace of change in the market if we look at the year on year change between 2013 and 2012, it clearly indicates the gradual shift of the market from its old duopoly structure to new oligopoly structure. If we look at credit card global purchase transaction count the credit card industry as a whole grew by $12.1 \%$ in 2013 . However both Visa and MasterCard's growth rates of $9.5 \%$ and $9.6 \%$ respectively are lower than that. JCB managed a $20.7 \%$ growth while UnionPay registered a mammoth $44.8 \%$ growth rate. 


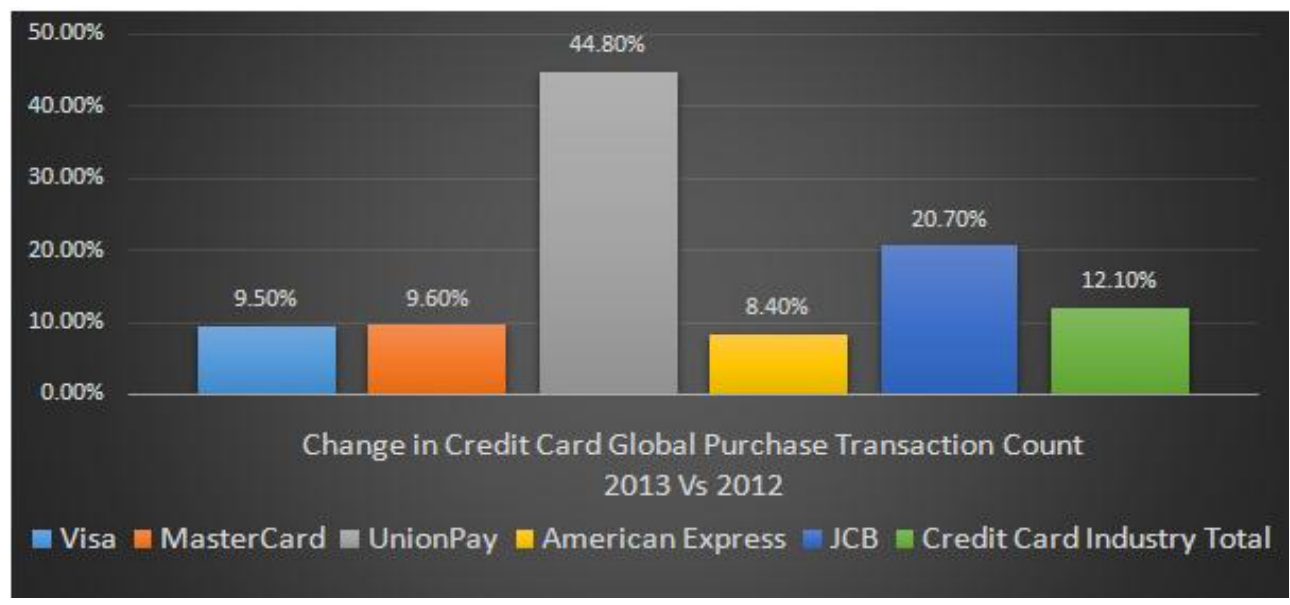

* Source-Nilson Report

Credit card global purchase transaction dollar volume is an important parameter to judge the market characteristics. In this respect the credit card industry as a whole grew by $18.4 \%$ in 2013 . However both Visa and MasterCard's growth rates of $11 \%$ and $11.6 \%$ respectively are lower than that. JCB grew by $19.8 \%$ which is more than industry growth rate. While UnionPay grew by a whopping $60.4 \%$.

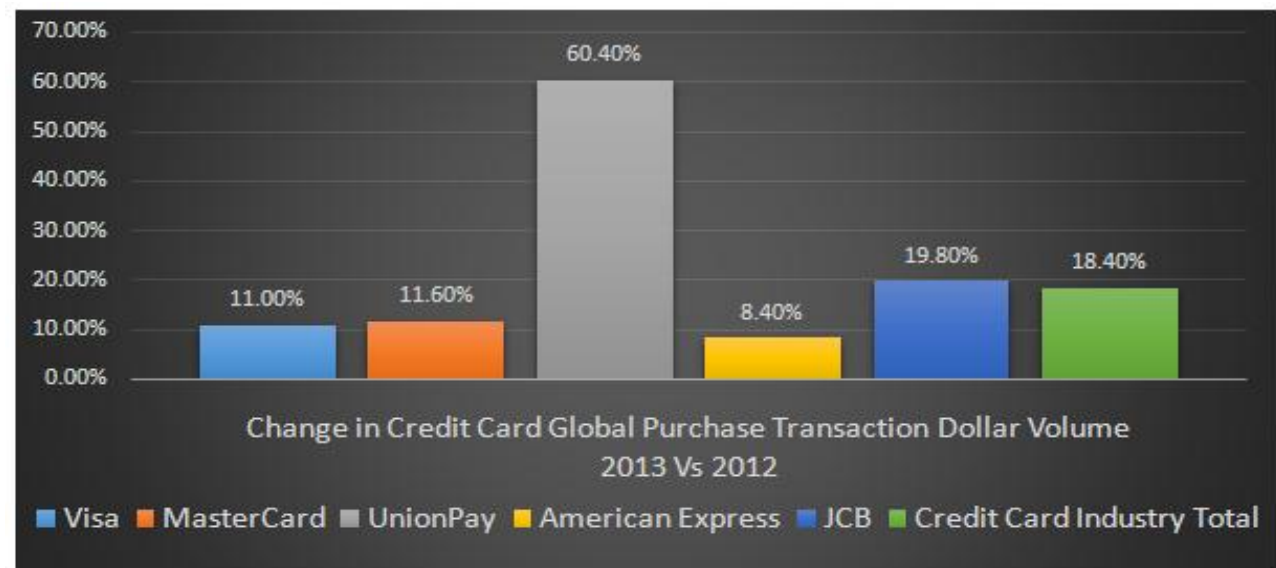

* Source-Nilson Report

If we look at credit card (in circulation) count the credit card industry as a whole grew by $5.8 \%$ in 2013. However both Visa and MasterCard's growth rates of $2.4 \%$ and $4.5 \%$ respectively are lower than that. Both Amex and JCB fared better than them in this parameter - Amex managed to increase card base by $4.7 \%$ and JCB by $5.2 \%$. However the biggest winner in this segment is UnionPay which expanded the card base by $18.1 \%$.

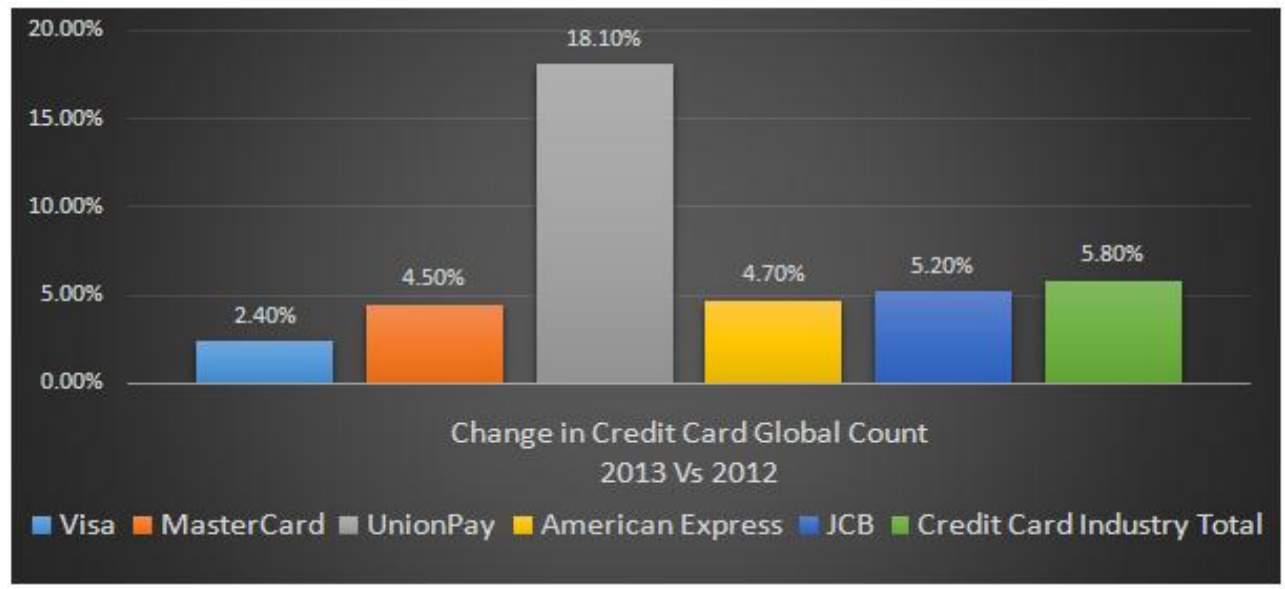

* Source-Nilson Report 
A Quick Peek at the Future Growth Projection of different regions (2012 to 2018):

Glancing through the future growth projection data as published by Nilson Report suggest that US and Asia Pacific regions would be the two key regions where the card schemes have to focus more. Asia Pacific is expected to grow by $145 \%$ and may have around 71 Billion purchase transaction count. Its expected percentage share at the end of 2018 would be close to $25 \%$. Though the US percentage share is expected to fall by $4 \%$ but it is expected to grow by an impressive $58 \%$ and may have around 120 Billion purchase transaction count. In order to do a more detail assessment of the global market structure and understand its future trend we need to take a closer look into US and Asia Pacific markets.
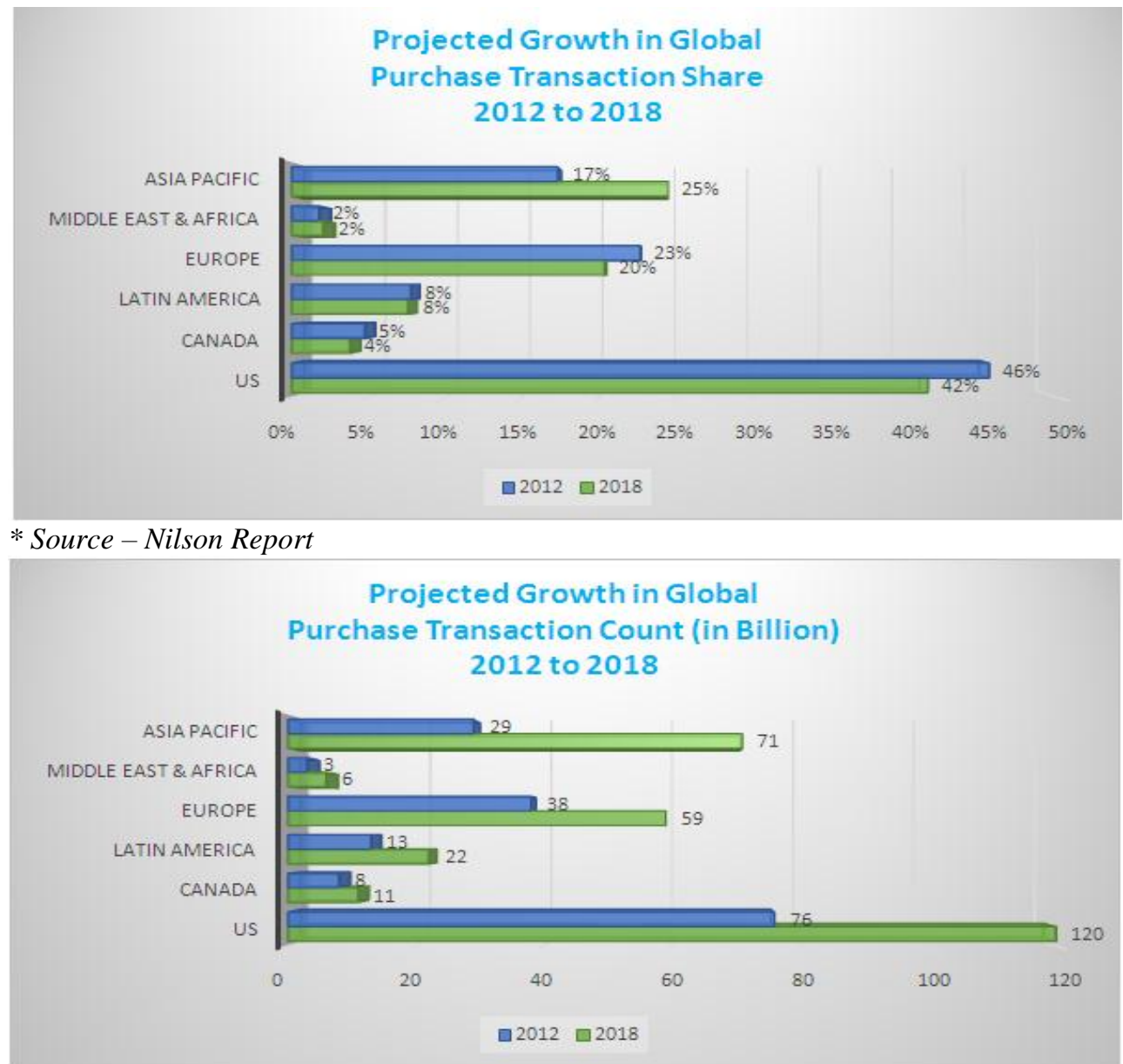

* Source-Nilson Report

\section{US Market Structure:}

A closer look into the US market suggests the same shift from the duopoly structure as seen in the global market. Based on the historical purchase volume data of top 4 players of US market, it is observed that Amex has surpassed MasterCard in 2011 and the gap further widened in 2012.

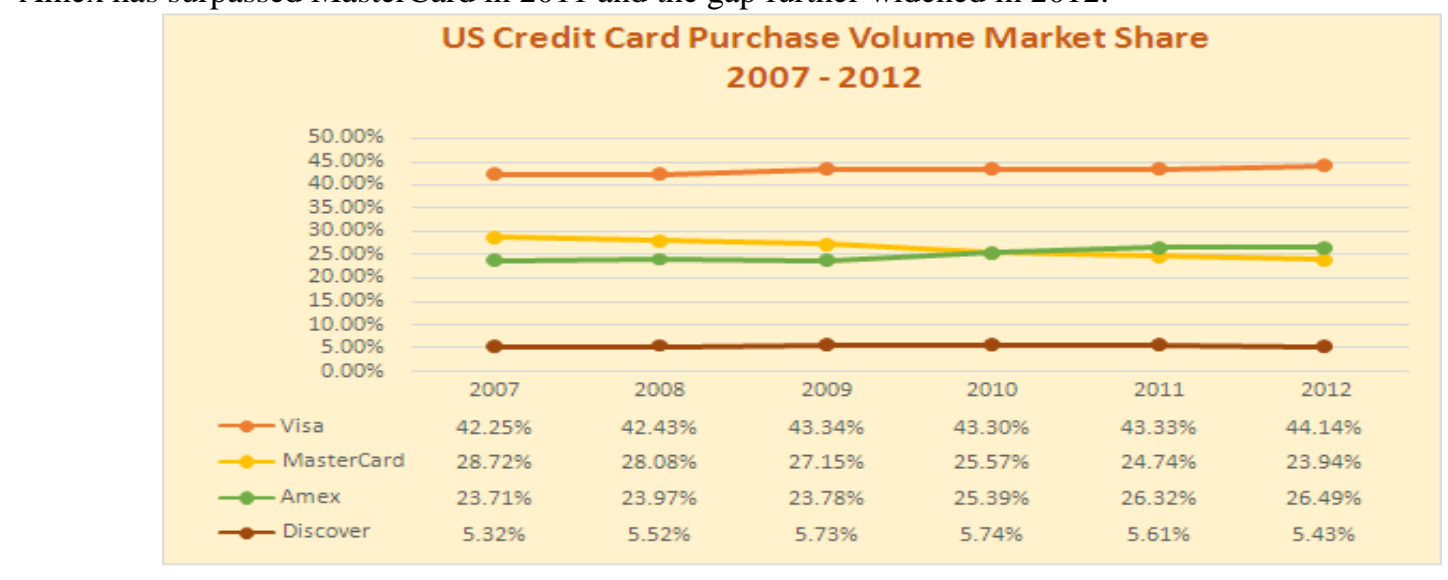




\section{* Source-Nilson Report}

JCB is not among the top 4 but in 2006 it entered into a major reciprocal agreement with Discover network. As part of the agreement in 2007, Discover Network began enabling its systems so JCB cardholders could use their JCB cards at Discover Network merchant locations throughout the United States. JCB too began enabling its system so that starting in 2008 the Discover Network cardholders could use their cards for purchases at JCB merchant locations in Japan. Though the complete integration in US took some more years, however following the agreement JCB card acceptance locations started increasing at a rapid pace and surpassed 5.5 million in 2012. For US consumers JCB currently offers six different cards products.

Union Pay too is having acceptance agreement which enables their cards to be accepted in Discover network and Elavon (global acquirer) network inside US following their agreement with Discover in 2005 and with Elavon in 2011. However they are yet to launch their own card product for US consumers.

On a whole analysis of US market reveals that Amex is having a good market share in US and have already surpassed MasterCard placing itself as the closest competitor to Visa. JCB and UnionPay are increasing their US presence gradually but yet to command a significant market share. But their gradual strategic moves suggest that both are trying hard to get a larger pie of the US market.

\section{Asia Pacific Market Structure:}

In the Asia Pacific regions the markets of China (World's second largest economy in terms of nominal GDP) and Japan (World's third largest economy in terms of nominal GDP) are dominated by UnionPay and JCB respectively. In fact most of the global transaction volume of these two players come from Asia Pacific region and specifically from their domestic economies. The mammoth growing economies of China and Japan that serve as their core markets is definitely a huge strength for them. UnionPay was established in March 2002, under the approval of the State Council and the People's Bank of China. At present, the Shanghai-headquartered UnionPay has about 400 domestic and overseas associate members and has strong backing of government. Both Visa and MasterCard are finding extremely hard to penetrate much in the Chinese card market as there is Chinese Government rule that protect UnionPay which even prompted them to take the case to WTO. In 2012 after a U.S. complaint, the World Trade Organization (WTO) ruled that China must stop discriminating against foreign payment companies by maintaining a monopoly on cards denominated in renminbi (yuan). However actual change in ground reality due to the ruling is yet to be assessed. Both UnionPay and JCB are aggressively working to expand the base in Asia Pacific Region. Both are entering into agreements with various organizations (like banks, financial institutions, other card schemes etc.) to increase their card acceptance and also to add more domestic issuers in those countries. JCB which started its journey a long time back has been able to sign agreement with banks and other financial institutions of 11 countries excluding Japan (China, Hong Kong, Indonesia, Laos, Singapore, Republic of Korea, Philippines, Malaysia, Taiwan, Thailand and Vietnam) in the region to act as issuers on their behalf. New agreements and growing cooperation with Shinhan Card Co. Ltd. (Korea), NongHyup Bank (South Korea), Kasikorn bank (Thailand), HSBC bank, banks of Australia (National Australia Bank, ANZ, Commonwealth bank) and banks of Pakistan (Habib, Faysal, AlBaraka) are some of the strategic moves made by UnionPay in last one year. In 2003, JCB and UnionPay signed a major reciprocal cooperation agreement which allowed China UnionPay network acceptance of JCB Cards in China and JCB network acceptance of UnionPay cards in Japan. On June 10, 2011 they signed a memorandum of understanding to expand their existing strategic relationship and to develop potential new areas of cooperation. This can be seen a major milestone in their attempt to grab larger share in Asia Pacific and even beyond. This mutual agreement would definitely aid growth of both the players.

A very interesting development is currently taking place in the Indian market (which is currently World's 10th largest economy in terms of nominal GDP and $3^{\text {rd }}$ largest economy in APAC region). Inspired by the huge success of Chinese Union Pay, RuPay card scheme was set up by NPCI (National Payments Corporation of India). The idea of setting up RuPay was conceived by Indian Banks Association and has the approval of Reserve Bank of India. Presently, there are ten core promoter banks which include both public and private sector banks (State Bank of India, Punjab National Bank, Canara Bank, Bank of Baroda, Union bank of India, Bank of India, ICICI Bank, HDFC Bank, Citibank and HSBC). Though RuPay is mainly perceived as domestic card scheme but NPCI has entered into a strategic partnership with Discover Financial Services (DFS) which will allow RuPay Global Cards to be accepted on Discover's global payment network outside India. RuPay currently has 78 member banks and 149 sub member banks. RuPay debit cards were first launched in March, 2012 and they are aiming to launch credit cards by end of 2014. As of September, 2013 there are around 6 million cards in circulation and RuPay cardholders can use their debit cards at all ATMs in India (around 1,20,000 ATMs) and in 25-30\% POS terminals (out of around 1 million POS terminals). NPCI is expecting that the RuPay card base will touch 150 million in next 2-3 years. Looking at the wide reach of RuPay it seems that once RuPay credit cards are launched by end of 2014, it would surely emerge as a tough domestic competitor for Visa \& MasterCard and they may lose their current dominance in Indian market. 
On a whole the Asia Pacific market appears to be highly challenging. Undoubtedly entry of any new credit card scheme would make it even more competitive in future. The success of the domestic card scheme may encourage other nations of the region to launch their own domestic card schemes. The internal alliances of the card schemes is also an extremely important event which would have long term implications and would have its far reaching impact even beyond Asia-Pacific region. Their tie ups with Discover Financial Service is giving their cards much needed acceptance at international level which in turn is acting as stimulus for increase in card base. The Asia Pacific credit card payment scheme market seem to be heading towards a complete oligopoly structure with at least six prominent players.

\section{Strategy analysis of global challengers:}

The three global challengers - UnionPay, Amex \& JCB were able to break the clutch of Visa \& MasterCard and snatch significant market share. Let us undertake an analysis of some of their strategies which acted as differentiators, have helped them to overcome the entry barriers and reshape the market from its previous Duopoly structure.

A. Low cost domestic processing: The domestic card schemes of APAC region is processing transactions domestically, which in turn has led to lower cost of clearing and settlement compared to international card schemes like Visa, MasterCard. This cost advantage is one of the prime reason of their high domestic penetration. This also can be cited as one of the reason why they were able to survive in the market where all players have to follow low profit margin business model.

B. Penetration into unexplored market: The domestic card schemes have successfully penetrated the unexplored rural customer segment thus shifting expenditure from cash to electronic payments. Since the rural consumer base was huge these card schemes were successful to operate in a scale where they can get the advantage of economy of scale.

C. Government backing in domestic economies: The domestic card schemes of APAC enjoy government backing which has led to their rapid expansion in their home turf. The rapid expansion in card base and acceptability at merchant locations have helped them to reach breakeven sooner.

D. Providing card issuance capability to domestic banks: Domestic card schemes have provided card payment service option to many banks who are not eligible for card issuance under the eligibility criteria of international card schemes. This in turn has helped them to penetrate untapped market segment.

E. Alliance between card schemes: The alliances between card schemes like UnionPay, JCB, RuPay and Discover for acceptance of each other cards in their networks have allowed the cards to quickly offer international acceptance to their consumers. Thus the cards gained popularity among international travellers as well.

F. Agreements with domestic and foreign card issuers: The card schemes have entered into agreements with various domestic \& foreign banks and financial institutions to act as card issuers on their behalf. This has helped them immensely to increase their card base. For example: Amex previously used to issue their card only on their own but now they have 10 US banks (like Bank of America), foreign banks like Bank of China (China), ICICI bank (India), financial institutions (like GE Money) and even retailers like Macy's acting as issuer on their behalf. JCB currently has issuing agreements with institutions belonging to 16 foreign countries of Asia, America, Europe and Middle East. Similar agreements have been made by UnionPay as well.

G. Special focus on specific market segment: One of the strategy adopted by the card schemes was to focus on specific merchant segment. For example Amex had been trying hard to impress SMB (small \& medium business) merchants with its various offering and campaigns like OnePoint, Small Business Saturday, Shop Small etc. Amex recently launched another new product called OptBlue which will help it to cut down the interchange fee from its current 3.5\% (which is higher than 2-2.5\% rate of Visa / MasterCard) and help it compete with Visa \& MasterCard. Reputed analysts including Morgan Stanley's Betsy Graseck expects the new product could help Amex increase their market share significantly.

H. Additional Offering: This feature is typically displayed by Amex. It started Merchant Financing business in 2011 for SMB merchants. Amex accepting small merchants can avail highly price-competitive (could be as low as 6\%) commercial loans based on their annual card processing volume. They can opt for 
Monthly Financing or Annual Financing based on their need and can use that to cover their operational cost or their growth requirements. This kind of additional offering can become a future trend for card schemes.

I. Merger \& Acquisition: Payback (loyalty partner with significant presence in Germany, Poland and India) acquisition by Amex in 2011 can be seen as a strategic M\&A move to increase its market share. Postacquisition Amex is aggressively offering Amex cards to Payback loyalty cardholders.

J. Latest Technology Offering: The card schemes too are providing their customers latest technology offerings in areas like fraud protection (e.g. EMV card, online authentication key like Amex Safe Key), ecommerce and $\mathrm{m}$-commerce etc. Thus the card holders are getting those latest features even without switching to Visa or MasterCard.

\section{The Road Ahead:}

The worldwide credit card payment scheme market seem to be undergoing a transformational change. It is clearly heading towards an Oligopoly structure from the previous Visa \& MasterCard dominated Duopoly structure. UnionPay, Amex and JCB are appearing to be the harbinger of the change. Their strategies are surely paying off and helping them in increasing their market shares.

It seems, that apart from the existing 5 prominent global players (who commands more than $1 \%$ of the global market) many domestic credit card schemes will make significant progress in their domestic markets and will eventually debut in the global market. Entry of those new players in the market would surely make it more competitive. Consumers will be benefitted by presence of multiple producers who would offer them homogenous product. Among new entrants apart from Indian RuPay which is set to launch its credit card by end of 2014 we have Elo in Brazil which is the $7^{\text {th }}$ largest economy (in terms of nominal GDP) of the world. According to London-based Lafferty Research, Elo (which started issuing cards in 2011 after its re-launch) has already captured 3\% domestic credit card market share in 2013.Lafferty forecasts Elo taking four percent by 2015, while the combined market share of Visa and MasterCard will be around 83 percent by 2015, down from 89 percent in 2010. Their progress in domestic market would further reduce market share of Visa and MasterCard. Though both of them are perceived as domestic card schemes but once they get a foothold in their huge domestic economies they are likely to follow the footsteps of UnionPay and gradually enter into the markets of other nations. Attempts are going on currently to create a Pan European card scheme as well. Huge success of UnionPay would surely encourage emergence of more card schemes whose journey would start as domestic scheme in huge economies.

In future intense competition will force the card schemes to lower cost and come out with new innovative offerings. This may also lead to product differentiation and in turn creation of niche market segments. Internal agreements between smaller players would act as stimulus for their growth. Collectively all these changes would cause further erosion of market share of Visa \& MasterCard and would also change the credit card payment scheme market landscape significantly.

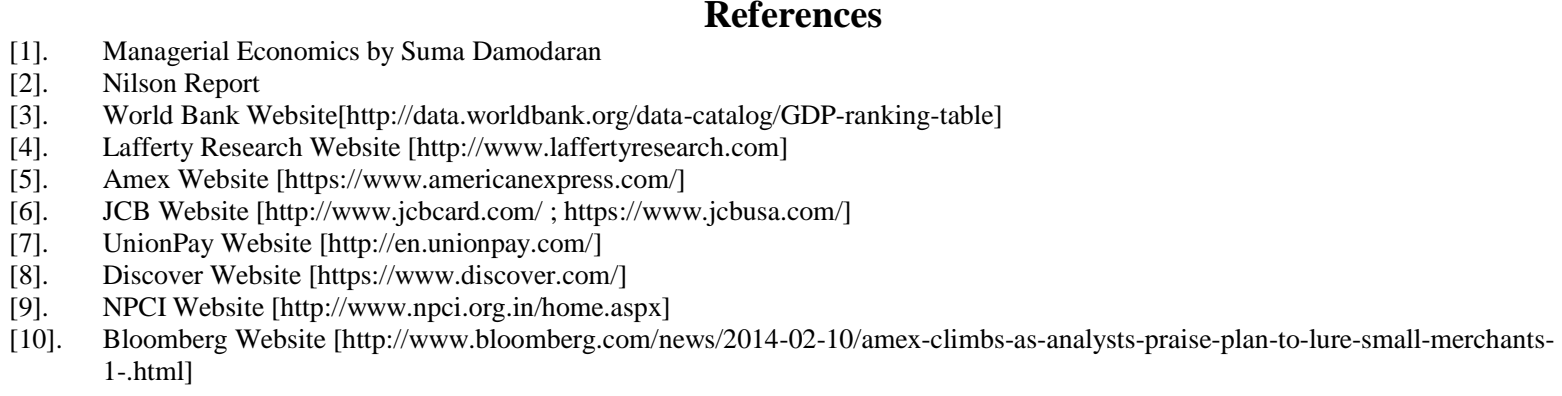

